\title{
Research on Graduation Design of Undergraduate Based on Long Term Teaching Mechanism
}

\author{
Ning ZHAO \\ School of Economic and Management \\ Shijiazhuang Tiedao University \\ Shijiazhuang, China \\ e-mail: Zz_ning860@ sohu.com
}

\author{
Haiming JING \\ School of Information \\ Shijiazhuang Tiedao University \\ Shijiazhuang, China \\ e-mail: jimperlov@yeah.net
}

\begin{abstract}
Graduation design of undergraduate as for time scale is small and it is difficult to guarantee the quality. In view of this question, discusses from the students with each course graduation design around the long-term teaching mechanism, coupled with a variety of extracurricular activities in catalysis, improving the quality of graduation design but also enable students to professional courses has been consolidated.
\end{abstract}

Keywords-long term teaching mechanism; extracurricular; graduation design

\section{INTRODUCTION}

Graduation design of undergraduate is a very important practical teaching engineering in higher education systems engineering, and is a key teaching process link to train students' comprehensive ability and improve their comprehensive quality and ability in theory and practice. he content of graduation design is very wide, putting forward more advanced requests for students in the width of knowledge , the depth of knowledge, the ability to deal with the actual problem, experiment ability, the level of foreign language, computer skills, written and oral expression ability.

There is a great difference between the undergraduate and the master's degree and the doctor's degree. Most of the time is to learn basic courses and the time for graduate design is less, which result in that the graduation design being neglected and separated from the former knowledge. And also the result in the design process and the paper writing are not ideal. Undergraduate graduation design flow chart is as shown in the following figure 1, we can discovered through the research that the reason is multiple, teacher, guide method, topic do not reach the designated position and the management cause, such as ensure measures, rewards and punishment system should not be ignored.

The long-term mechanism of teaching and learning is a new perspective, which can fully guarantee the systematicness and continuity of knowledge. As soon as the students enter the university, teachers begin to guide them into the role of the graduation design. Teachers sum up their various practices according to their graduation design guiding, experiencing it into the teaching process, experiment and course design. And also through the participation of all kinds of competitions and the injection of teachers' scientific research to provide useful support for students' graduate design.

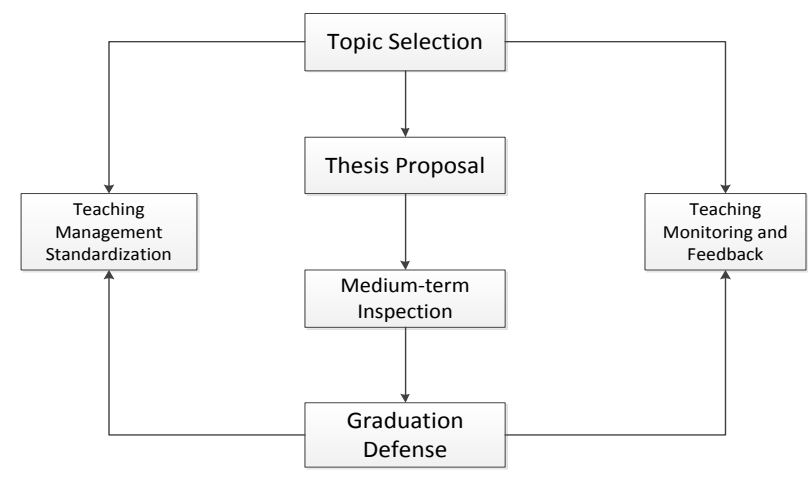

Figure 1. Undergraduate graduation design flow chart

\section{DISCUSSION ON COURSE RELATING TO GRADUATE DESIGN}

Wherever Times is specified, Times Roman or Times New Roman may be used. If neither is available on your word processor, please use the font closest in appearance to Times. Avoid using bit-mapped fonts if possible. True-Type 1 or Open Type fonts are preferred. Please embed symbol fonts, as well, for math, etc.

\section{A. The Teaching of Professional Courses for the Graduation Design}

Each basic courses, specialized basic courses and specialized courses in university has a perfect system, and the connection between the courses is very close. Each course has its subtleties. These connections between the courses and graduate design requires teachers in the teaching process to emphasize the significance and value of the basic knowledge theory to solve the practical problems according to the previous experience in guiding the design of the students. Students from freshman will continue to strengthen the consciousness of using the knowledge to solve practical problems .

The engineering professional course oriented application is more closely related with the graduation design. In the teaching process, desalinating examination and paying attention to practice approach should be adopted, which can enable student's practical knowledge to be consolidated and sublimated and avoid the inflexibility of knowledge and the lacking of practical ability. 


\section{B. Cultivate the Ability in Experimental and Centralized Curriculum Design}

The related experiment and the centralized design of the course may play a very key role in the preparation of graduation as well. The experiments include confirmatory experiments and design experiments from the easy to the difficult. The proportion of confirmatory experiment' is larger. Thronging a certain number of confirmatory experiment training, the student can master systematic knowledge, and then students can be asked to select design experiment according to their own interest and knowledge levels. This process can give full play to students' creativity, making the students' practice ability being improved.

The subject of curriculum design requires being comprehensive, its task quantity is less than the quantity of graduation design and its knowledge structure is relatively single. But seriously do a good job in every course design will make teachers' own scientific research methods, the perceptual knowledge and practical ability to obtain remarkable promotion and also will help students to complete their graduate design better and faster.

\section{EASE OF USE STUDY ON THE CURRICULUM RELATED TO THESIS WRITING}

The above is the design level in the graduation thesis. On the other hand, How to express your own design is also a key section. Graduation thesis is the deduction of student's design, in the thesis they should have their own view. One can also refer to previous research thought, research method and even repeat previous research work, but prerequisite is that they have their own opinions. Now the paper's format change from the handwriting to computer printing and typesetting, every part is stipulated strict pattern. The train of thoughts in the main text should be clear, so that readers can understand the design content intuitively. The other part must be standardized and the chart should be clear. The final papers should be a fine piece of work.

In the teaching of scientific writing, teachers should train the writing ability of the students in order to cultivate their writing standardization. When the students complete the graduation thesis, they won't spend much time in thesis format.

\section{A. The Importance of English Abstract Writing}

English abstract in graduation thesis is to meet the foreign communication and to facilitate the retrieval, its literary style emphasize on scientificity, logicality, accuracy and rigor. therefore the graduation thesis abstract must be clear and correct in technology concept and highlight the logical relationship. Particularly in the professional term should conform to the usual practice English, consistent with the English for science and technology science, rigorous feature. The English abstract writing in undergraduate graduation thesis is little, but the development has many problems, such as the Chinese type English, word for word and sentence for sentence translation etc.. In recent years, the thesis has increased in foreign-language translation of information project, requirements of the translation of the foreign language must be with subjects related literature.

Professional foreign language is a course related to English abstract. in the process of course teaching, teacher should provide students the opportunities in translating and writing orienting graduation thesis abstract, which can play a multiple effect.

\section{B. The Importance of Literature Retrieval Course}

The topic of graduation thesis must be novel. To achieve this goal, one must look up the relevant literature extensively, apprehend the work of the formers or the others, and point out the deficiency or blank, finally ascertain a new topic and research direction. But when beginning graduate design, a considerable part of undergraduate students can not use the abundant literature data and information in the library, the literature retrieval ability is far behind the practical requirements of graduation thesis writing.

In view of the above situation, in literature retrieval course teacher should consciously guide students to look up some literature, library and teaching units should communicate each other, to provide students with the network academic resource navigation service, let the students be familiar with libraries and other information retrieval, read the article combining with their knowledge and interest, and know the state of the course. All these action are doing for the writing of graduation thesis and make literature retrieval ability penetrate into the course teaching. Through the cultivating of literature retrieval ability, enable students to develop and make full use of resources of learning habits and become a lifelong learner.

\section{THE CATALYTIC EFFECT OF EXTRACURRICULAR ACTIVITIES ON THE GRADUATION DESIGN}

\section{A. Guiding Students to Participate in Various Competitions Actively}

National Mathematical Modeling, electronic design, mechanical design competition provide the student the opportunity to train practical ability, team cooperation ability and even innovation ability. The content of the competition and the professional course system are closely related, but also adapt to the thinking of combining the theory and practice in undergraduate education. In the whole process there include design, design report writing and the respondent, the depth and breadth is no less than graduation design. In addition, college students' science and technology festival also offers students a platform for innovation.

\section{B. Teachers' Scientific Research Providing Fresh Blood for the Graduation Design}

Fusing manufaction, education and research is the actual demand of higher engineering education, which will be the basic requirement of the graduation design teaching in major of engineering. Teachers should reduce the virtual topic, and guiding students to participate in scientific research to make practical use of the knowledge. For example, the topics of graduation design in recent three years of School of 
economics and management is as shown in the following figure 2 .

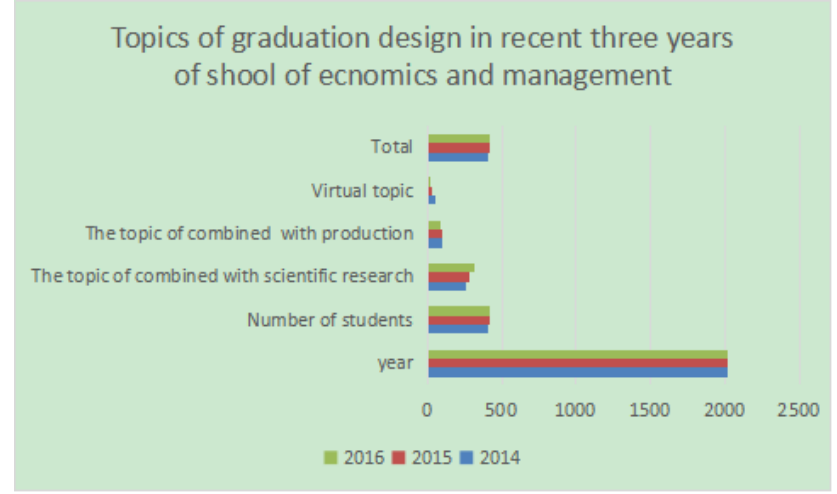

Figure 2. Topics of graduation design in recent three years of school of economics and management

And the ratio condition in recent years of graduation design guidance teachers in school of economics and management is as shown in the following TABLE 1.

TABLE I. THE RATIO CONDITION IN RECENT THREE YEARS OF GRADUATION DESIGN GUIDANCE TEACHERS IN SCHOOL OF ECONOMICS AND MANAGEMENT

\begin{tabular}{|c|c|c|c|c|}
\hline year & students & professor & $\begin{array}{c}\text { associate } \\
\text { professor }\end{array}$ & lecturer \\
\hline 2014 & 404 & 13 & 28 & 12 \\
\hline 2015 & 414 & 15 & 28 & 14 \\
\hline 2016 & 421 & 16 & 31 & 14 \\
\hline
\end{tabular}

\begin{tabular}{|c|c|c|}
\hline assistant & teachers & $\begin{array}{c}\text { ratio of teachers } \\
\text { and students }\end{array}$ \\
\hline 3 & 56 & $1: 7.21$ \\
\hline 2 & 59 & $1: 7$ \\
\hline 1 & 62 & $1: 6.7$ \\
\hline
\end{tabular}

In the process of participating in the vertical and horizontal subjects, teachers should overcome their corresponding drawbacks, making appropriate changes to enable students participate in the purpose better and reaching a win-win situation. The vertical subject reflects the trend of technology development, reflects the academic and theoretical depth. The research results are introduced to the students will explore and cultivate their creativity. The organization of the undergraduate students to participate should pay attention to assign task to students to avoid overcome their knowledge. The horizontal project focus on the realization and application, which is suitable for undergraduate students to participate in. But during the process students should be avoided doing simple repetitive work. Otherwise, students can not get effective practical exercise, and the help of graduation design is also very limited.

\section{The Cultivation of Interdisciplinary Talents in the Course of Graduation Design}

Interdisciplinary approach can overcome the problem of a single professional knowledge, broaden the students' knowledge, and provide more extensive space for future employment. Teachers can organize the students to learn from each other among the various professional. Understanding the whole subject thought when completing their own sub project is to cultivate students' comprehensive quality. The topic of graduation design will be more flexible, and it is advantageous to cultivate the talents of compound engineering technology. Through a multi-interdisciplinary graduate design, on the one hand it will be a suitable platform to the students to learn from each other to enhance their awareness of cooperation and to reflect their team spirit better; on the other hand, multi-interdisciplinary graduate design is also put forward higher requirements to teachers. So, it will be a challenge both for teachers and for students.

\section{ACKNOWLEDGMENT}

This work was supported by the follows: (1)The Young Foundation of Education Department of Hebei Province(No.QN2017139) (2)The Young Foundation of Shijiazhuang Tiedao University. (No. 20153011)

\section{REFERENCES}

[1] X.D.YUAN, X.LIU, Training Mode on Graduation Design of Engineering Students Based on the Dual-Tutor System, 258-260, PEEE 2015.

[2] Xiaokai Xing, Changchun Wu. Practice and exploration on the graduation design directed by school-enterprise cooperation of research university, Educational reform. 5 (2011)84-86.

[3] Zhenyu Wang. The discussion on how improve the Improve the gradua-tion design quality of engineering undergraduate, The innovation on science and technology. 30 (2011)176-177.

[4] Yuying, Research and Practice of the Teaching Method of Programcontrolled Switching Principles, Journal of Chengdu University Educational Sciences Edition, vol 24, No.5, 2010.

[5] Xiaokai Xing, Changchun Wu. Practice and exploration on the gradua-tion design directed by school-enterprise cooperation of research univer-sity, Educational reform. 5 (2011)84-86. 